\title{
Food Price Shocks and Political Unrest
}

Author: Bobby Joe Trail

Faculty Mentor: Idean Salehyan, Department of Political Science, College of Arts and Sciences, University of North Texas

Department and College Affiliation: Department of Political Science, College of Liberal Arts, East Central University 
Food Price Shocks and Political Unrest 2

\section{Bio:}

Bobby Joe Trail was born on January 16, 1986, in Oklahoma City, Oklahoma. He is working toward a Bachelor of Arts degree in Political Science at East Central University in Ada, Oklahoma. He is a combat veteran and was honorably discharged from the United States Marine Corps at the rank of Sergeant after serving almost six years. He is a NASA Fellow and recently participated in a NSF-REU summer research program in Civil Conflict Management and Peace Science at the University of North Texas. He will present his work, "Food Price Shocks and Political Unrest” at the Midwest Political Science Association Conference in April, 2012. Trail's research interests include American politics, public policy making, campaigns and elections, and legislatures. His future plans are to pursue a graduate degree in Political Science as well as study Constitutional Law. 
Food Price Shocks and Political Unrest 3

\begin{abstract}
:
Since 1990, global food prices have been trending upward and when the price of food rapidly spikes or there are price shocks, instances of mass political unrest have been recorded. Most notably, the rapid food price shocks in 2007-2008, and most recently in 2010-2011, created mass protests in the Middle East and Africa. The existing literature fails to address the fact that although these global food price shocks result in extensive political unrest in some countries, other countries remain altogether free of political unrest. The premise of this research is to help fill the gap in the existing literature and provide answers to why some countries experience protests to global food price shocks while others do not. The general theory behind this research is that highly urbanized populations feel the effects of food price shocks more than highly rural populations, and that net food importers of food are more likely to experience protests when food prices spike. I used a negative binomial regression model to demonstrate the proposed relationship between events of political unrest recorded by the Social Conflict in Africa Database and food price shocks.
\end{abstract}


Food Price Shocks and Political Unrest 4

\section{Introduction}

Since 2007-2008, rising food prices have been a catalyst for conflict all over the world. As global food prices rise and fall, the impacts are experienced throughout poor developing countries that import the majority of their food. In April, 2008, the price of cereals on the global market increased more than 25 percent and this price shock directly correlated with news reports of violent protests in Egypt, Senegal, Cameroon, and Cote d'Ivoire that resulted in at least two dozen deaths. Egypt, a net food importer of cereals, was rocked with protests in reaction to the price shocks, while at the same time, no protests were recorded in comparable countries such as Angola, Namibia, and Ethiopia. There are several variables that contribute to the rise and fall of food prices but the ways in which a country deals with the shocks differ on a case by case basis. The question this paper will address is: why do food price shocks result in political unrest in one country but not in another?

There is an abundance of literature explaining the factors in rising food prices as well as how rising food prices can lead to civil war and conflict; however, there is a gap in the literature on why protests occur in some places and yet is relatively absent in others. Lower levels of violence such as protests, riots, and demonstrations, are important to understand because by nature, they are typically less expensive and have fewer opportunity costs for individual participation than civil war. Food price shocks are shared on a global market but the effects are experienced differently in every country. Countries that import the majority of their food from the global market are at the mercy of rapidly changing prices or shocks. Protests have been recorded that directly coincide with these price shocks. This paper focuses on food price shocks and how they lead to protests in some countries while similar countries fail to experience 
political unrest. In theory, a country that is a net importer of food and primarily urbanized will be most likely to experience protests, while at the same time a food producing, agriculturally diverse population would be less likely to experience political unrest.

First, this paper addresses the factors that create protest/riots/demonstrations and through the existing literature, explains how these factors play a role in inciting political unrest. Second, I will discuss the theory and hypotheses I have developed to answer the research question. Third, I will discuss the methodology of this research and describe the operationalization of the variables used for determining the answer to my research question as well as the model used to test my hypotheses. Finally, I will report my empirical findings and explain how they are relevant to answering the research question.

\section{Literature Review}

In this review of the literature, the focus will be on food price shocks and their effect on events of political violence/unrest. The majority of the literature in this area focuses primarily on civil war and other armed conflict (Besley and Persson 2009; Miguel, Shanker, and Sergenti 2004; Sambanis 2001). There is a small but growing literature that focuses on price shocks and the impact on protests/riots/demonstrations. However, the focus of this paper is to determine why food price shocks create protests in some countries but not in others. Currently, there is no literature that focuses on this relationship directly; therefore, this review will encompass a broad overview of what causes food price shocks and subsequently, how they can create or lead to protest.

There are several arguments as to what conditions produce the phenomenon of rising food prices. Previous literature concludes that population growth, weather, economic growth, 
Food Price Shocks and Political Unrest 6

rising energy prices, increasing cost of agricultural production, and supply and demand are the key factors contributing to food price increases (Alexandratos 2008; Bates 2011; Kasara 2007; Tadesse et al. 2008; Trostle 2008). All of the above conditions have an influence on the rising costs of food prices and each author presents the reasons why in their respective works. The conclusions derived from these works illustrate how certain factors play their roles in the rising costs of food prices.

Climate change plays a significant role as well. Frequent droughts in the last few years have resulted in food crises for many countries and millions of people of Africa; however, while drought alone is not necessarily the cause of food crises, it can often be a trigger for food insecurity (Tadesse et al. 2008). The price for basic food commodities has spiked several times during the past two years, and many factors have contributed to these rapid price shocks including an increase in the global demand for bio-fuels feed-stocks, adverse weather conditions, the devaluation of the U.S. dollar, rising energy prices, and increases in agricultural costs of production (Trostle 2008). With rising energy costs, the focus shifts from oil dependency to alternative energy sources resulting in food sources being allocated to bio-fuel feed stocks. Subsequently, weather conditions play a role in the production of the food sources whose supplies are already being diverted to other uses. When all of these factors collide, a perfect storm is formed that leads to rapidly increasing food prices on the global food market. When food prices increase substantially from one month to the next, the result is called a price shock.

Alexandratos (2008) introduces the rising energy prices argument with a particular emphasis on bio-fuels as well as the argument that emerging economies also have a significant impact on the market price of foodstuffs, notably China and India. "Strong economic growth in 
Food Price Shocks and Political Unrest 7

the emerging economies, particularly in China and India, is commonly cited as a major cause of the rise in food prices (e.g., IMF 2008a: 60). The head of the International Food Policy Research Institute [Joachim von Braun] stated in 2008 that 50 percent of the price increase was due to strong income growth, while bio-fuels accounted for another 30 percent” (2008: 672). Once again, the literature shows that energy prices and the demand for bio-fuels are creating a strain on the demand for food stuffs.

Lastly, weather and climate change has been widely cited to have an effect on resource scarcity (Hendrix and Glaser 2007; Hendrix, Haggard, and Magaloni 2009; Hendrix and Salehyan 2011). When climates change and weather patterns are altered, food production is directly affected. For instance, when a flood strikes a region resulting in degraded production of food, the effects are felt not only in that region but on the global markets as well. The same is true with droughts and various other weather related phenomena.

Understanding what causes food prices to increase is important in understanding how they correlate to protests. Hendrix, Haggard, and Magaloni (2009) define [protests] demonstrations and riots "as acts of collective action, some peaceful and others violent, that publicly signal a grievance against the existing government” (6). When food prices sharply increase over a very short period of time resulting in a price shock, protests have commonly been observed. The current gap in the literature regarding this issue demonstrates a need for scholarship linking political unrest and rapidly increasing food prices. Food insecurity is greater in sub-Saharan African countries than it is in other developing countries throughout the world and the problem of food security could further deteriorate with the current global food commodity demands and higher fuel energy prices because most nations in sub-Saharan Africa 
Food Price Shocks and Political Unrest 8

are net importers of food and energy (FAO 2002, 2005). World record food prices caused a mixture of protests and violent riots in over thirty different African countries in 2007-2008. The literature shows that high food prices constitute a threat to human security. The countries that have witnessed the hardest impacts have been countries at lower levels of economic development that are also net food importers (Brinkman and Hendrix 2011, Trostle 2008).

"Food is the basic of all necessities and as a result is the one commodity most likely to be seen as embodying an explicit or implicit political entitlement” (Hendrix, Haggard, and Magaloni 2009, 10). Hendrix, Haggard, and Magaloni conclude that higher food prices benefit producers (not dependent on market purchases), but are associated with higher living costs for consumers. Food price shocks clearly constitute a grievance for consumers; however, the reverse is also true. Falling food prices negatively impact the rural sector but benefit the urban sector, and the motivation to protest is once again likely (2009). "As prices rise, in percentage terms, the quantity of food demand does not decline proportionately. Instead people cut back on their consumption of other goods in order to feed themselves and their families” (Bates 2011, 2). This is a basic principle of "Engel's Law" which states that the percentage of a person's income spent on food declines as the level of income rises. While food may be a necessity, people only need to consume so much. “As Engel's Law suggests, once having fulfilled their food needs, they spend additional income on other goods” (2011).

Research by Carter and Bates (2011) suggests first, that urban dwellers maintain their power over public policy formation even in majoritarian settings because of their ability to react to policy changes, essentially becoming swing voters. Second, they argue that when governments create policy to respond to food price shocks in favor of farmers, the probability of conflict 
Food Price Shocks and Political Unrest 9

increases. Therefore, governments in developing countries faced with food price shocks have a greater likelihood of political stability by favoring the urban sector (2011).

Research focusing on food price shocks and protest is limited and in light of recent world developments, a rapid increase in political unrest is expected. Thus, the focus of this research centers on explaining why political unrest erupts in response to food price shocks in some countries but not others. Food price shocks are experienced globally and comparable developing countries are logically expected to react similarly, but this expectation has not been realized. In recent years protests to food price shocks have been witnessed in several countries but many countries have remained immune to political unrest. The question that this paper seeks to explain is, why?

\section{Theory}

If all countries experience the effects of the food price shocks, why do protests occur in some countries but not others? Food price shocks can and have led to protests, and previous literature suggests that increased food prices have a direct impact on the income of poor people living in developing countries. When food prices increase, people do not buy less food but rather spend a greater percentage of their income on food, thus spending less on other consumer goods (Bates 2011). Although the entire country experiences the effect of food price shocks, it will likely have distinctive consequences in different areas of a country. Food producers in rural areas will likely profit from this development while those living in urban areas will be most vulnerable to the negative effects of rising food prices. In addition to profiting from food price shocks, the rural sector will be less likely to protest for several reasons. First, the collective action problem is much more difficult to resolve in rural areas. The ability to organize people 
who are scattered and geographically dispersed is more difficult than organizing individuals who are geographically concentrated in urban areas. Second, the rise in food price costs may be counteracted by farmers who engage in subsistence farming, whereby they can grow food for themselves and are less likely to be burdened by the rising food prices. Although subsistence farming may counter balance against rising food prices for the rural population, it does not provide the same relief to the urban population as they lack access to arable land. However, the divide between urban and rural areas of a country does not completely explain the existence of mass protests in one country and not in others.

The type of agriculture grown within a country may also play a significant role as not all farmers grow edible agriculture or engage in subsistence farming. In many countries, farmers specifically grow cash crops such as coffee, tea, cotton, or tobacco that often employ a large sector of the workforce. Although many people are involved in farming on cash crop farms, the agriculture cultivated on this type of farm does not contribute to the food markets, allowing the country to be vulnerable to global food price shocks. Countries that grow cash crops tend to import the majority of their food for consumption and with the majority of the population employed in the rural sector, food price shocks are expected to have a huge impact on livelihood.

H1: During global food price shocks, countries with a higher urban population will experience political unrest.

Based on these observations, I argue that food price protests are most likely in highly urbanized countries that are net importers of food and in countries that employ a large portion of the workforce in agriculture that produces cash crops and is therefore forced to import a majority of its food. On the other hand, countries that export food crops and have a majority of their 
population living in rural areas are less likely to experience political unrest due to food price shocks.

While food price shocks unambiguously lower the welfare of urban consumers, their impact upon the welfare of rural dwellers depends upon whether the shortages that generate them arise abroad or domestically. If they arise abroad, domestic producers will benefit from the price rise. If the shortages arise domestically, however, then the loss of crops - and incomes - of the rural dwellers needs to be added to the economic losses in the urban economy (Bates 2011: 3).

Countries that primarily import their food are typically at the mercy of the fluctuating market price of food which has steadily increased since the 1990s. Highly urbanized countries or countries with an agricultural sector focused primarily on cash crops must import food at market prices in order to feed their populations. Thus, when global food prices sharply increase, the populations feel the full effect of the price shock and respond to this development with mass dissent. When both the urban and rural sectors are subjected to the effects of rapidly increasing market prices, protests would seem most likely. Egypt is an example of a country that has a large urbanized population and imports the majority of its food. When cereal prices on the global market spiked in early 2008, protests were rampant across the country. Egypt is a net food importing country which means that it relies solely on the world market prices for food in order to feed its population. Since Egypt is mainly covered by deserts, there are no arable lands and consequently, no agricultural sector. Egypt relies on tourism as the biggest industry and thus employs the majority of its population in the urban sector. Consequently, when protests break out they take place in large cities such as Cairo and Alexandria.

H2: During global food price shocks, countries that import the majority of their food will experience political unrest. 
Countries that are producers of their own food, on the other hand, are more likely to employ the largest sector of their population in the rural sector. When a country is a food producer, the effects of the global markets are less dramatic than a non-food producing country because they have the ability to keep resources at the local level. Farmers or citizens employed in the agricultural sector producing food are likely to grow food for themselves before becoming reliant on the global markets. Furthermore, when demand and market prices increase, the income of those employed in the rural sector should also increase. Thus, these countries are less likely to experience protests because a significant aspect of their population profits from the increase of market food prices. Therefore, the increase in food prices should produces an increase in the incomes of those involved in agriculture. In this case, where income matches the rising costs of food prices, protests would be the least likely.

\section{Research Design}

The sample I use for this research is all countries in Africa with a population over one million within the time frame of 1990-2010 in order to determine why food price shocks lead to protests in some countries while at the same time, other countries produce no protests. There are 937 observations. All of the countries used in the sample have a full twenty years of

observations. For the sample, I will be using the number of recorded events of political unrest for each country. There are more than 6,000 recorded events overall during the twenty year time period. Within this study I will use the country and the year (country-year) as a unit of analysis.

\section{Dependent Variable}

To measure the dependent variable, the number of events of political unrest (protest, riots, and demonstrations), I use a variable measuring the number of events per year for each country as 
designed in the Social Conflict in Africa Database (SCAD) (www.scaddata.org). The database covers the time period 1990 through 2010 and lists over 6,000 protests, riots, strikes, coups, communal violence, and other types of social unrest compiled by Associated Press (AP) and Agence France Presse (AFP) news wires (Hendrix, Salehyan, Linebarger, Stull, and Williams 2010). Using SCAD, I constructed a count variable for my dependent variable of the number of political unrest events per country per year. I tried using the number of political unrest events as a dependent variable but it was difficult to distinguish what was related to food, water, and subsistence, and what was not.

In my data set, each country is organized by year and the number of SCAD events for each country. The distribution of my dependent variable ranges from zero (zero recorded counts of political unrest) to ninety-five (South Africa in 1995 had 95 instances of political unrest). The dependent variable for recorded events is represented in the model as events.

\section{Independent Variables}

To measure the independent variable, Food Price Index (foodpriceindex), I used data regarding global food market prices compiled from the Food and Agriculture Organization (FAO). The FAO Food Price Index is a list of the monthly food price indices averaged over the course of the year. It consists of the average of five different commodities weighted by the average export shares for 2002-2004 (FAO). The five commodity price indices used are: meat, dairy, cereals, oils and fats, and sugar. The data was collected from the FAO website (http://www.fao.org/worldfoodsituation/wfs-home/foodpricesindex/en/) and the full index is available for download at its website. In addition to providing a variable for food price index, I created a variable to represent the change from one year to the next. The variable ( $f p_{-}$change) 
Food Price Shocks and Political Unrest 14

represents the amount of change in the food price index from the food price index of the previous year. Furthermore, I constructed a variable for the percent change in the food price index from the previous year as a percentage ( $\left.f p \_p c t c h a n g e\right)$.

The variable for urban population (urban_pct), represents the percent of total population that reside in urban areas. The data for the urban population variable was obtained through the World Bank World Development Indicators. "Urban population refers to the people living in urban areas as defined by national statistical offices. It is calculated using World Bank population estimates and urban ratios from the United Nations World Urbanization Prospects” (http://data.worldbank.com).

In order to test my theory and hypotheses, I constructed a variable representing net food importing countries. The variable for food importers (nfic) was created by taking FAO database numbers for cereal exports and subtracting them from cereal imports in order to determine if the country was a net importer of cereals (wheat, rice paddy, barley, maize, rye, oats, millet, sorghum, buckwheat, quinoa, fonio, triticale, canary seed, and mixed grain) (FAO 1994). I then created a dichotomous variable by assigning a " 0 " if the number was less than zero, meaning that it was not a net food importer and " 1 " if the number was greater than zero, meaning that it was a net food importer.

I also created an interaction variable representing the effect of the food price index and whether or not the country was a food importer (fp_nfic). It is expected that when interacted with the food price index, net food importing countries will have a greater impact on events of political unrest. I created this variable by multiplying the variable for net food importing countries (nfic) with the variable for food price index (foodpriceindex). 
Finally, I included several control variables within the model. First, the type of government may be a decisive factor in the number of protests, riots, and demonstrations that take place within a country. If a country is fully democratic, we expect that certain institutions within the government would be devised to provide a buffer or safety net during food price shocks. Furthermore, if citizens have the right to vote and those in power have displayed that it will allow for the change in leadership, the citizens of the country would have the means to alter the government if those in power fail to provide a safety net. To empirically measure the type of government of the country, I used the Polity 2 variable from the database compiled by the Polity IV Project: Political Regime Characteristics and Transitions. Polity 2 is an adjusted variable of the original Polity variable, modified for use in time series analysis. The original Polity variable measured the type of government by subtracting the level of autocracy from the level of democracy to achieve the final variable. In this dataset, the variable, Polity 2, ranges from -10 (full autocracy) to a +10 (full democracy) (Marshall and Jaggers 2000).

Second, a variable representing the Gross Domestic Product of a country (log_GDP) was also added to the model to test if GDP logged over time would have any effect on the number of events of political unrest. It is expected that higher levels of logged GDP will have a negative impact on higher levels of political unrest. With a higher GDP a country would have more flexibility when it comes to a shock in market prices. This variable is measured in U.S. dollars and comes from the Penn World Tables. The Penn World Tables are arranged in time series format and the entries are denominated in a common set of prices in a common currency (U.S. Dollars) to allow for easy comparison (Heston, Summers, and Aten 2009).

Finally, I included variables for my dependent variable lagged (events_lag) and a variable 
for total population (total_pop). The variable for events lagged was used with the expectation that an event in one year will increase the likelihood of future events in the next year. Total population was used as a control for the total population of each country included in the dataset.

\section{Methodology}

In this analysis, I argue that there is a relationship between global food price shocks and urban population as well as global food price shocks and net importing countries. In order to test this relationship, I will use a Negative Binomial Model because my dependent variable is a count variable of events per country per year over time. To test this relationship, I cannot use ordinary least square (OLS) because using an OLS model with dependent variable of event count data may lead to inaccurate and inefficient estimates (Long 1997).

\section{Analysis}

\section{Model 1 Using the Food Price Index}

The results for Model 1 using a negative binomial regression model with the food price index as my dependent variable are reported in Table 1. The analysis focuses on the relationship between food prices and events of political unrest. In this first model, the food price index is used in order to test the hypotheses that urban population and net food imports have an impact on events of political unrest. It is expected that food prices and the percentage of urban population will have a significant impact on the number of events of political unrest as well as food prices and whether or not the country is a net food importer. In addition, I have added several other independent variables and controls in order to observe their effects on events of political unrest. These include percentage of urban population (urban_pct), net food importing countries (nfic), log of GDP (log_GDP), polity II score (polity2), total population (total_pop), and events lagged 
(events_lag). Therefore, the equation being tested is:

\section{events $=\aleph_{0}+\beta_{1}$ events_lag $+\S_{2}$ foodpriceindex $+\beta_{3}$ urban_pct $+\S_{4}$ nfic $+\S_{5}$ log_GDP + $ß_{6}$ polity2 + $_{7}$ total_pop.}

The initial results show that the effect of the food price index variable representing yearly food prices indices, although significant, has a negative impact on events. It is significant at the .05 level and based on its IRR value when increased by a margin of 1 the likelihood of events decreases. In other words, the higher the yearly food price index then the lower the likelihood of political unrest. This finding is drastically counter intuitive to my theory and further research is owed to this phenomenon.

Although the main independent variable for food price index has not performed in the expected manner, other independent variables including urban population are highly significant to the likelihood of events of political unrest. The variable urban_pct is highly significant at the .05 level and according to the IRR, given a 1 unit increase in percentage of urban population, the effect on the dependent variable is an increase of 1.011352 in events of political unrest. This clearly indicates that with an increase in the percentage of urban population, protests become more likely. Similar to foodpriceindex, insignificant results were found for the variable for food importing countries. The variable nfic, was not only insignificant, but was shown to have a negative impact on events. The model implies that a 1 unit increase in food importers will result in a .8835 decrease in the likelihood of events. This once again is counter intuitive to the expected result. The expected result would be that a net food importing country would have an increased likelihood of political unrest. This first model using food price index failed to support both hypotheses, and on two accounts directly contradicted the reasoning behind the hypotheses. 
Food Price Shocks and Political Unrest 18

\section{Model 2 \& 3 Using Food Price Change and Percent Change}

Although the initial analysis produced some significant findings, many of them were unexpected and at times, seem somewhat unreasonable. Therefore, two similar models with changes to my independent variables may be appropriate to discover the relationship between events of political unrest and food price changes. In the first model, I used a variable for food price index and the results were the exact opposite of what was expected. In the second model, I used a variable for percent change of food price index ( $\left.f p \_p c t c h a n g e\right)$ from the previous year. In the third model, I substituted the variable for percent of food price change with a variable representing actual food price change from the previous year ( $\left.f p \_c h a n g e\right)$. Table 2 and Table 3 represent model 2 and model 3 respectively.

In the second and third models the other independent variable used are: events lagged, percentage of urban population, food importing countries, and an interaction of food price index*food importing countries. The following variables are used as controls: log of GDP, polity II, and total population. The equations for model 2 and model 3 are as follows:

Model 2 using percent change of food price index

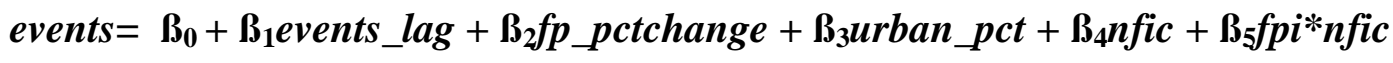

$$
\begin{aligned}
& ß_{6} \log _{-} G D P+\beta_{7} \text { polity2 }+\beta_{8} \text { total_pop. }
\end{aligned}
$$

Model 3 using actual change of food price index

events $=\beta_{0}+\beta_{1}$ events_lag $+\beta_{2} f p \_$change $+\beta_{3}$ urban_pct $+\beta_{4} n f i c+\beta_{5} f p i{ }^{*} n f i c$ $ß_{6} \log _{-} G D P+ß_{7}$ polity2 $+ß_{8}$ total_pop.

By using a variable for change of food price index, both models 2 and 3 become completely significant. The percent change of food price index used in model 2 is significant at 
the .001 level and implies that a 1 unit rise in percent change will yield a 1.012 increase in the likelihood of events. This model predicts the expected result that a change in the food price index will create an increase in the likelihood of events of political unrest. This finding is consistent with the theory and confirms the hypothesis that a change in the food price index will lead to more political unrest.

The variable for actual change of food price index used in model 3 becomes significant at the .001 level as well, implying that a 1 unit increase in change will result in an increase of events by 1.010. Just as in model 2, this model produced expected results, the expectation being that a positive change in the food price index will result in an increase in the likelihood of events of political unrest. The only differences in model 2 and 3 are the main independent variables; all other variables performed almost identically.

The variable for percent of urban population (urban_pct) becomes significant at the .1 level and implies that a 1 unit increase in urban population increases the likelihood of political unrest by a value of 1.008. As in the first model, the variable for the percent of urban population stands to prove hypothesis one; the higher the urban population the greater the likelihood of political unrest.

As hypothesized, whether or not a country was a net food importer would be expected to have a positive increase of events. In models 2 and 3, the variable for food importers (nfic) was found to be extremely significant at the .001 level and resulted in an increase in the likelihood of events by 3.501 and 3.375 respectively per 1 unit increase. These models support the hypothesis that countries that import the majority of their food are more likely to experience political unrest when food prices change. 
Food Price Shocks and Political Unrest 20

Model 2 and 3 included an interaction variable to test if there was any significance on the impact of the food price index multiplied by food importers (fpi*nfic). This interaction variable proved to be extremely significant to the .001 level, but once again suggests that when interacted, there is a negative impact on the likelihood of events. While this is expected because in model 1 , food price index also had a negative effect on events as well, this is counter to my expectations that protest events should increase in net food importing countries when there is an increase in the food price index.

All but one of the control variables were significant. The variable included for GDP logged over time (log_GDP) was significant at the .05 level and implied that a 1 unit positive increase of logged GDP would decrease the likelihood of events by .79. This is consistent with my expectations. It only makes sense that the higher the GDP, the less likely the political unrest, and the opposite is also true. In other words, when a country has a higher GDP, it would be more apt to combat political unrest by absorbing the effects of the price shock, and vice versa. Total population was significant at the .001 level and implies that a 1 unit increase in population would result in a steady 1.000013 and 1.0014 increase.

\section{Conclusions}

Food price shocks have incited widespread political unrest but not all countries experience the effects in the same manner. The purpose of this research is to help determine why some countries experience protests, riots, and demonstrations in reaction to rapidly increasing food prices, while at the same time, other countries remain immune from unrest. I constructed several models in order to test my hypotheses and using a count variable for political unrest events as my dependent variable, I tested my models using a negative binomial regression model. 
Food Price Shocks and Political Unrest 21

This study has attempted to quantitatively test the merits of the relationship between food price spikes on the events of political unrest. I tested this relationship using a sample of 47 countries during the period of 1990-2010.

In the course of this research, I ran several models in order to measure the relationship between certain variables on the likelihood of events of political unrest. Model 3 proved to be the most impressive model. By including the variable for the change in food prices from one year to the next, as hypothesized, the percent of urban population and whether or not a country imports food became statistically significant. In this model, all variables included, with the exception of Polity II, were highly significant as well. This model suggests that a positive change in the food price index along with a highly urbanized population would create more protest in net food importing countries.

Model 1, although counterintuitive, provided very interesting results. Model 1 included the independent variable for food price index and when tested in the model had a negative effect on the number of political unrest events. This could be explained in several ways; first, the food price index is equally applied to all countries across the globe, therefore, when comparing a single year at one price, it would not be expected to incite political unrest. Second, most of the countries in the sample have primarily rural populations, and as per my theory, when food prices increase, the wages for those employed in the agricultural sector increase as well. In this case political unrest would be unexpected. As wages increase, the population has a larger income and is then able to cope with rising food prices and when prices spike, feel the effects less than those with lower incomes. Not until I included a variable for change in food prices was my hypotheses confirmed. 
Food Price Shocks and Political Unrest 22

Most of the literature in this area addresses civil wars and although civil war is extremely important to understand, events of political violence/unrest are far more frequent. Understanding what creates these lower level events of political unrest can be beneficial to understanding how they escalate to higher levels. This research aims at bridging the gap in the existing literature by providing insight as to what creates lower level political unrest. The implications of my research show the types of situations that contribute to an increase in political unrest.

In future iterations of this paper, I aim to include a more effective measure of food prices. Using the food price index on a yearly basis may not be the best choice for this research. I will include a measure of food prices based on actual prices of food measured in dollars per ton. Furthermore, this paper uses the country-year as the unit of analysis for all of the variables. Future work would be improved by using country-month as the unit of analysis. A more accurate interpretation of the effect of events could be attained by observing each country on a monthly basis because the monthly food price changes could be used and compared to the number of political unrest events per month. This may be difficult because the databases that are currently used for this project publish only annual data. I believe that future work in obtaining more data at lower levels of analysis could prove beneficial not only to this research but for the political science community as a whole.

This research could provide insight for policymakers, researchers in the sub-field, and political scientists alike. Policymakers could use the findings in this research to aid in the decision making process when it comes to events of political unrest. 
Food Price Shocks and Political Unrest 23

\section{Bibliography}

Alexandratos, N. (2008). "Food Price Surges: Possible Causes, Past Experience, and Longer Term Relevance.” Population and Development Review, 34(4):663-697.

Bates, R. (1989). Beyond the Miracle of the Market: The Political Economy of Agrarian Development in Kenya. New York: Cambridge University Press. . (2011). “Food Price Shocks \& Political Instability.” CMM Discussion Paper No.3.

Besley, T. and Persson, T. (2009). "State Capacity, Conflict and Development.” NBER Working Paper, No. 15088.

Brinkman, H. \& Hendrix, C. (2011). "Food Insecurity and Conflict: Applying the WDR Framework”. World development Report Background Paper.

Carter, B. and Bates, R. (2011). Food Price Shocks. Cambridge MA, Weatherhead Center of International Affairs, Harvard University.

Food and Agriculture Organization (FAO) of the United Nations. (2000). Multilateral Trade Negotiations on Agriculture 2000. Food and Agriculture Organization, Rome Italy. . (2002). The State of Food Insecurity in the World 2001. Food and Agriculture Organization, Rome, Italy. . (2005). The State of food and Agriculture. Food and Agriculture Organization, Rome, Italy.

Food and Agriculture Organization (FAO) of the United Nations. http://www.fao.org/worldfoodsituation/wfs-home/foodpricesindex/en/.

Haile, M. (2005). Weather patterns, food security and humanitarian response in sub-Saharan Africa. Philosophical Transactions of the Royal Society B, 360(1463): 2169-2182.

Hendrix, C. and Glaser, S. (2007). "Trends and Triggers: Climate Change and Civil Conflict in Sub-Saharan Africa.” Political Geography 26(6): 695-715.

Hendrix, C., Haggard, S., \& Magaloni, B. (2009). "Grievance and Opportunity: Food Prices, Political Regime, and Protest.” International Studies Association Convention, New York, February 15-18.

Hendrix, C., Salehyan, I., Case, C., Linebarger, C., Stull, E. and Williams, J. (2010). "The Social Conflict in Africa Database: New Data and Applications.” Working paper, the University of North Texas. 
Hendrix, C. and Salehyan, I. (2011). The Brewing Storm? Climate Change, Rainfall, and Social Conflict in Africa. Policy Brief February 2011. Austin, TX: Strauss Center CCAPS.

Heston, A., Summers, R., and Aten, B. (2009). "Penn World Table Version 6.3. Center for International Comparisons of Production, Income and Prices.” University of Pennsylvania.

IMF. (2008a). “Financial Stress, Downturns, and Recoveries.” World Economic Outlook. Washington DC.

Kasara, K. (2007). “Tax Me if You Can: Ethnic Geography, Democracy, and the Taxation of Agriculture in Africa.” The American Political Science Review, 101(1): 159-172.

Long, S. (1997). Regression Models for Categorical and Limited Dependent Variables. Thousand Oaks, CA: Sage.

Marshall, Monty G. and Keith Jaggers. (2000). "Polity IV Project: Political Regime Characteristics and Transitions, 1800-2000”, Retrieved August 16, 2011 at http://www.cidcm.umd.edu/inscr/polity/.

Miguel, E., Shanker, S., and Sergenti, E. (2004). "Economic Shocks and Civil Conflict: An Instrumental Variables Approach.” Journal of Political Economy 112(4):725-753.

Sambanis, N. (2001). A Review of Recent Advances and Future Directions in the Quantitative Literature on Civil War. Manuscript. New Haven, Connecticut: Yale University.

Tadesse, T., Haile, M., Senay, G., Wardlow, B., \& Knutson, C. (2008). “The need for integration of drought monitoring tools for proactive food security management in sub-Saharan Africa.” Natural Resources Forum, 32(4):265-279.

Trostle, R. (2008). "Global Agricultural Supply and Demand : Factors Contributing to the Recent Increase in Food Commodity Prices (WRS-0801, May 2008).” Washington, D.C.: Department of Agriculture.

World Development Indicators, The World Bank. www.data.worldbank.org. 
Food Price Shocks and Political Unrest 25

Table 1: Model 1 using Food Price Index

\begin{tabular}{|l|r|r|r|r|r|}
\hline \multicolumn{1}{|c|}{ Variables } & \multicolumn{1}{c|}{ IRR } & \multicolumn{1}{c|}{ Std. Error } & \multicolumn{1}{c|}{$\mathbf{P}>|\mathbf{z}|$} & \multicolumn{2}{c|}{$\mathbf{9 5 \%}$ Conf. Interval } \\
\hline Events Lagged & 1.05 & .003 & $0.000^{* * *}$ & 1.009962 & 1.019967 \\
\hline $\begin{array}{l}\text { Food Price } \\
\text { Index }\end{array}$ & .992 & .003 & $0.003^{* *}$ & .9872718 & .997428 \\
\hline Pct Urban & 1.01 & .005 & $0.023^{*}$ & 1.001584 & 1.021216 \\
\hline $\begin{array}{l}\text { Net Food } \\
\text { Importers }\end{array}$ & .883 & .169 & 0.517 & .6074769 & 1.285074 \\
\hline Log of GDP & .786 & .065 & $0.004^{* *}$ & .6677517 & .9252488 \\
\hline Polity2 & 1.01 & .008 & 0.141 & .9961014 & 1.027759 \\
\hline $\begin{array}{l}\text { Total } \\
\text { Population }\end{array}$ & 1.00 & $3.38 \mathrm{e}-06$ & $0.000^{* * *}$ & 1.000008 & 1.000022 \\
\hline
\end{tabular}

Note: a. Dependent variable: Number of events (SCAD)

b. An $(*)$ indicates statistically significant at the .1 level

c. An $(* *)$ indicates statistically significant at the .05 level

d. An (***) indicates statistically significant at the .001 level

e. $\mathrm{N}=689$

f. Wald Chi2=232.83 
Food Price Shocks and Political Unrest 26

Table 2: Model 2 using Percent Change of Food Price Index

\begin{tabular}{|l|r|r|r|r|r|}
\hline \multicolumn{1}{|c|}{ Variables } & \multicolumn{1}{c|}{ IRR } & \multicolumn{1}{c|}{ Std. Error } & \multicolumn{1}{c|}{$\mathbf{P}>|\mathbf{z}|$} & \multicolumn{2}{c|}{$\mathbf{9 5 \%}$ Conf. Interval } \\
\hline Events Lagged & 1.02 & .003 & $0.000^{* * *}$ & 1.009986 & 1.020346 \\
\hline FPI Pct Change & 1.01 & .003 & $0.000^{* * *}$ & 1.00601 & 1.01817 \\
\hline Pct Urban & 1.01 & .005 & $0.081^{*}$ & .9989319 & 1.018425 \\
\hline $\begin{array}{l}\text { Net Food } \\
\text { Importers }\end{array}$ & 3.50 & 1.24 & $0.000^{* * *}$ & 1.751764 & 6.997624 \\
\hline FPI*NFIC & .988 & .003 & $0.000^{* * *}$ & .9822008 & .9932367 \\
\hline Log of GDP & .793 & .065 & $0.005^{* *}$ & .6748427 & .9318297 \\
\hline Polity2 & 1.00 & .008 & 0.955 & .9830595 & 1.016265 \\
\hline $\begin{array}{l}\text { Total } \\
\text { Population }\end{array}$ & 1.00 & 3.35e-06 & $0.000^{* * *}$ & 1.000007 & 1.00002 \\
\hline
\end{tabular}

Note: a. Dependent variable: Number of events (SCAD)

b. An (*) indicates statistically significant at the 1 level

c. An $(* *)$ indicates statistically significant at the .05 level

d. An (***) indicates statistically significant at the .001 level

e. $\mathrm{N}=688$

f. Wald Chi2 $=242.46$ 
Table 3: Model 3 using Actual Change of Food Price Index

\begin{tabular}{|l|r|r|r|r|r|}
\hline \multicolumn{1}{|c|}{ Variables } & \multicolumn{1}{c|}{ IRR } & \multicolumn{1}{c|}{ Std. Error } & \multicolumn{1}{c|}{$\mathbf{P}>|\mathbf{z}|$} & \multicolumn{2}{c|}{ 95\% Conf. Interval } \\
\hline Events Lagged & 1.02 & .003 & $0.000^{* * *}$ & 1.010158 & 1.020489 \\
\hline FPI Change & 1.01 & .002 & $0.000^{* * *}$ & 1.00558 & 1.015009 \\
\hline Pct Urban & 1.01 & .005 & $0.100^{*}$ & .9984454 & 1.017906 \\
\hline $\begin{array}{l}\text { Net Food } \\
\text { Importers }\end{array}$ & 3.38 & 1.16 & $0.000^{* * *}$ & 1.717045 & 6.634543 \\
\hline FPI*NFIC & .988 & .003 & $0.000^{* * *}$ & .9827523 & .993435 \\
\hline Log of GDP & .794 & .065 & $0.005^{* *}$ & .6763571 & .9330402 \\
\hline Polity2 & .998 & .008 & 0.811 & .981589 & 1.014654 \\
\hline $\begin{array}{l}\text { Total } \\
\text { Population }\end{array}$ & 1.00 & $3.35 e-06$ & $0.000^{* * *}$ & 1.000007 & 1.00002 \\
\hline
\end{tabular}

Note: a. Dependent variable: Number of events (SCAD)

b. An $(*)$ indicates statistically significant at the .1 level

c. An $(* *)$ indicates statistically significant at the .05 level

d. An (***) indicates statistically significant at the .001 level

e. $\mathrm{N}=688$

f. Wald Chi2 $=245.73$ 